\title{
Influence of physical exercise in pain threshold in human: A systematic review
}

\author{
Zecchin-Oliveira $\mathrm{AM}^{1,2}$ and Poli-Neto $\mathrm{OB}^{1}$ \\ ${ }^{1}$ Ribeirão Preto Medical School (FMRP), USP-RP, SP, Brazil \\ ${ }^{2}$ School of Physical Education and Sport of Ribeirao Preto (EEFERP), USP-RP, Brazil
}

\begin{abstract}
Pain can be defined as an unpleasant sensory and emotional experience associated with actual or potential tissue damage or described in terms of that injury. Aerobic exercise has been widely studied in painful conditions subjects and is related for the improvement of the fragility syndrome, increasing the pain threshold/tolerance during and after its practice. For healthy subjects, aerobic exercise has already shown to prevent various diseases and strengthen the immune system, fighting infection diseases. The objective of this review was to report the modalities of aerobic exercises associated with the treatment of adjuvant pain or reduction of experimental pain (threshold or tolerance) in the skeletal muscle system through a systematic review of clinical studies.
\end{abstract}

The search was performed in the electronic databases PubMed, Web of Science and Scopus following PRISMA recommendation. Articles published between January 1980 and January 2019 were selected, reporting results related to pain modulation through aerobic exercise.

A total of 20,790 studies from which we evaluated 110 records and, finally, we included 7 studies in the quantitative analysis, following the eligibility criteria. The results revealed that healthy men and women (about 97 patients) increased the pain threshold /tolerance through aerobic exercise. Protocols with different stimulations were evaluated.

Conclusion: With low quality of evidence, it is indicated that aerobic exercise increases threshold / tolerance of peripheral pain in healthy people.

\section{Introduction}

Pain can be defined as an unpleasant sensory and emotional experience associated with actual or potential tissue injury or described in terms of this lesion [1]. It is fundamental to survival; acute pain demonstrates a harmful action given in a short period of time (by stimulation of delta nociceptive fibers in healthy people), but when the pain is chronic there is already an advanced inflammatory process and even a modulation of pain, given by time (by stimulation of the $\mathrm{C}$ fibers, when there is no central sensitization) [1-6].

In addition to the negative factors that pain promotes (as seen above), the high cost with health stands out. Pain has been highlighted as a "major socioeconomic problem" in various countries [7]. in the United States of America, at the beginning of 2012 an average of 116 million people were estimated to have a health problem (which brings discomfort and pain), with US $\$ 635$ billion spent on treatments annually [7]. One of the ways to classify pain is through the pain threshold, which can be defined as the minimum stimulus needed to trigger pain in the individual. Pain is a phenomenon of subjective measurement, which is difficult to measure [8]. Some methods have been developed to measure pain thresholds in a systematic way, such as: pressure stimulus [9-11], measurement with thermal variance [1214] and even use of electrical stimulation [15-17], making the more practical the understanding of pain in the various clinical pathologies and the severity of the diseases. These tools also allow for making experimental use of pain, in laboratories, for example.

Pain thresholds, in turn, are defined as minimum stimuli needed to induce or cause pain in the individual [18]. Studies involving both animals and humans have already demonstrated a possible association between chronic pain and reduction of pain thresholds [19,20]. Several factors determine these thresholds [21-23], one of the variables that has received great attention is physical exercise $[24,25]$.

It is already understood that physical exercise promotes pain improvement and prevents /treats plenty of diseases, such as: cardiovascular diseases, cancer, arthrosis, type II diabetes, obesity, among others [26-30]. Studies involving large populations have shown that physically active individuals have a significant decrease in the risk of developing chronic pain [31,32].

The mechanisms involved in pain relief by exercise can be orchestrated by activation of endogenous opioids, such as beta endorphin, dynorphin and enkephalin, a factor observed in animals but still contradictory in humans, and activation of baroreceptors, which are cells that are located in the aortic arch and carotid artery and respond to the regulation of cardiovascular parameters (heart rate and blood pressure), modulating the pain threshold/tolerance [33,34]. Exercise in general, both aerobic and anaerobic, plays a fundamental role in analgesia, since it increases heart rate, activating the baroreceptor mechanisms and relating to the descending system of pain modulation, increasing the threshold $[35,36]$.

${ }^{*}$ Correspondence to: Arthur M Zecchin-Oliveira, Ribeirão Preto Medical School (FMRP), USP-RP, SP, Brazil, E-mail: arthurzecchin@usp.br

Key words: pain threshold, pain tolerance, exercise training, aerobic exercise

Received: September 16, 2020; Accepted: September 30, 2020; Published: October 05,2020 
Aerobic exercise is characterized as a method that varies energy consumption and respiratory exchange (O2 and $\mathrm{CO} 2)$ with emphasis on the mobilization of fatty acids during its application, consuming more carbohydrate as the intensity of the training increases $[37,38]$. Aerobic exercise has been widely studied in subjects with painful conditions and is indicated for the improvement of the fragility syndrome by increasing the pain threshold during and after practice $[2,4,36]$. For healthy subjects aerobic exercise prevents various diseases and strengthens the immune system, becoming less exposed to contract an infection [5]. The objective of the present study is to identify, analyze and summarize existing evidence from randomized clinical trials investigating the effects of aerobic training on pain threshold and tolerance in healthy subjects.

\section{Methods}

This review followed the Preferred Reporting Items for Systematic Reviews and Meta-Analyses (PRISMA) statement [39]. There is a 27item check list in PRISMA, that focus on ensuring a complete reporting of health care interventions. The inclusion criteria are exposed in figure 1.

\section{Search strategy}

A search was conducted using the following electronic databases via MEDLINE: PubMed; Web of Science; and Scopus. We searched for study records at the ClinicalTrials.gov, Current Controlled Trials and WHO-ICTRP (World Health Organization-International Clinical Trials Registry Platform), as well as abstracts published in congress proceedings through the Web of Science.

The following key words used were: (Chronic pain and Train) OR (Chronic Pain and Exercise) OR (Chronic Pain and Physic) OR (Pain and fit) OR (Pain Perception and Exercise) OR (Sensitivity and Fit) OR and Exercise) OR (Tolerance and Fit) OR (Pain and Train) OR Pain Perception and Train) OR (Sensitivity and Exercise) OR (Sensitivity and Physic) OR (Sensitivity and Train) OR (Threshold and Exercise) OR (Threshold and Physic) OR (Threshold and Train) OR (Tolerance and Train).

\section{Eligibility criteria}

Studies evaluating aerobic exercise at any type were included in this review following the criteria: (1) healthy men and women at any

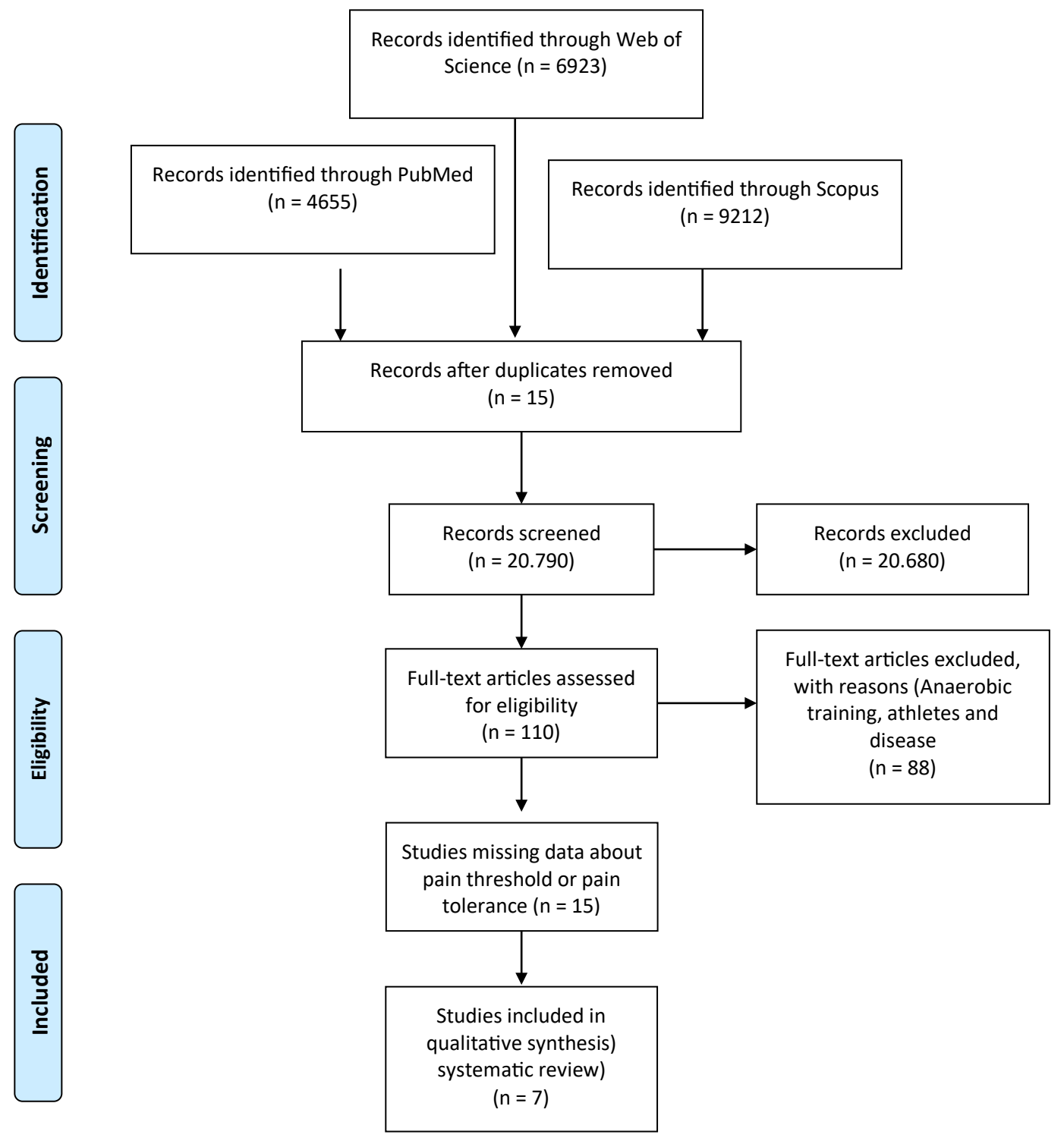

Figure 1. Flow diagram of screening and selection of articles for review 
age; (2) pain measurement method only with pressure algometer in any body region; (3) study design-published randomized controlled trials.

\section{Review process}

The selection of studies was carried out by titles, abstracts and key words that were independently reviewed by two authors (PNOB and ZOAM) verifying duplications and using pre-established criteria for inclusion. After the basic screening the same authors selected the studies following the eligibility criteria above by full reading. Regarding the language, only studies written in English or Portuguese were included.

\section{Data extraction}

Articles were included from January 1980 until January 2019.

The characteristics of the studies extracted were authors, country, date, institution, conflict of interest, consent term, ethical approval, inclusion and exclusion criteria, number of women and men in the study, exercise modality, exercise period, physical exercise time performed in each session, weekly training, menstrual cycle and anatomical site of the measurement of the pain threshold/tolerance.

There was contact with the authors of the studies to obtain missing data. In cases of no response, we opted to exclude them in order to avoid any discrepancy in the comparison values.

Methodological quality and strength of evidence

We consider study limitations (bias risks), inconsistency, imprecision, indirect effect and publication bias (following PEDro scale). The quality of the evidence was checked as: High quality = it is very unlikely to change our confidence in estimating the effect with further research; Moderate quality $=$ more searches are likely to have a significant impact on our confidence in the estimate of effect and may change the estimate; Low quality $=$ more surveys are very likely to have a significant impact on our confidence in the estimate of effect and is likely to change the estimate; Very low quality = we are uncertain about the estimate.

\section{Results}

A classification of eligibility criteria of each study is included in table 1.

The methodological quality and strength of evidence of all studies are unanimous in the results, the pain threshold/tolerance was increased after aerobic exercise (ergometric bicycle or treadmill). The data is showed in table 2 .

The characteristics containing the main information of each study are included in table 3.

\section{Discussion}

This systematic review exposes pain perception through pain threshold/tolerance in healthy subjects exposed to aerobic exercise. Seven studies were considered eligible, and based on the study classification, one study was classified as "moderate" in quality of evidence, three studies were classified as "low" in quality of evidences and three other studies were classified as "very low" in quality of evidences.

Aerobic exercise seems to modulate positively the pain threshold/ tolerance in healthy people during and shortly after its practice. In this sense, aerobic exercise, either performed in the form of walking or running on a specific ergometer (treadmill), or on a stationary
Table 1. Study classification following the inclusion eligibility criteria

\begin{tabular}{|l|l|l|}
\hline $\mathbf{N}$ study & Author/ year/ country & Eligibility \\
\hline $\mathbf{1}$ & Jones 2014, Australia & $\begin{array}{l}\text { 1- Healthy } \\
2-18-50 \text { years } \\
3-\text { No depression historic }\end{array}$ \\
\hline $\mathbf{2}$ & Oosterwijck 2012, Belgium & $\begin{array}{l}\text { 1- Woman } \\
2-18-65 \text { years } \\
\text { 3-Chronic } \text { Whiplash } \text { and Healthy }\end{array}$ \\
\hline $\mathbf{3}$ & Meeus 2010, Belgium & $\begin{array}{l}1-18-65 \text { year } \\
2-\text { Ability to perform ergometric bicycle }\end{array}$ \\
\hline $\mathbf{4}$ & Koltyn 1996, USA & ND \\
\hline $\mathbf{5}$ & Whiteside 2004, UK & ND \\
\hline $\mathbf{6}$ & Lee 2014, Korea & ND \\
\hline $\mathbf{7}$ & Hoffman 2004, EUA & Healthy Individuals \\
\hline
\end{tabular}

Note: ND, non-defied

Table 2. Evidence quality of the studies

Low quality evidence (Jones, 2014)

\begin{tabular}{|l|l|l|}
\hline Part/studies & Interpretation & Evid. Qual. \\
\hline $27 / 3$ & Pain & Low*
\end{tabular}

\begin{tabular}{|l|l|l|}
\hline $27 / 3$ & Pain threshold increased after exercise & Low*
\end{tabular}

* = one level Lowered by the methodology limitation by the methodology limitation

Moderate quality evidence (Oosterwijck, 2012)

\begin{tabular}{|l|l|l|}
\hline Part/studies & Interpretation & Evid. Qual.
\end{tabular}

\begin{tabular}{l|l|l}
\hline $44 / 0$ & Pain threshold increased after exercise & Moderate*
\end{tabular}

* = one level Lowered by the methodology limitation by the methodology limitation Low quality evidence (Jones, 2014)

\begin{tabular}{|l|l|l|}
\hline Part/studies & Interpretation & Evid. Qual.
\end{tabular}

\begin{tabular}{l|l|l}
\hline $27 / 3$ & Pain threshold increased after exercise & Low*
\end{tabular}

* = one level Lowered by the methodology limitation by the methodology limitation 3. Meeus, 2010.

\begin{tabular}{|l|l|l|}
\hline Part/studies & Interpretation & Evid. Qual. \\
\hline $78 / 0$
\end{tabular}

\begin{tabular}{|l|l|l}
\hline $78 / 0$ & Pain threshold increased after exercise & Low*
\end{tabular}

* = one level Lowered by the methodology limitation by the methodology limitation

4. Whiteside, 2004.

\begin{tabular}{|l|l|l|}
\hline Part/studies & Interpretation & Evid. Qual.
\end{tabular}

\begin{tabular}{|l|l|l}
\hline $44 / 0$ & Pain tolerance increased after exercise & Low*
\end{tabular}

* = one level Lowered by the methodology limitation by the methodology limitation

Very low quality evidence

5. Koltyn, 1996.

\begin{tabular}{|l|l|l}
\hline Part/studies & Interpretation & Evid. Qual
\end{tabular}

\begin{tabular}{|l|l|l}
\hline $16 / 0$ & Pain threshold increased after exercise & Very low*
\end{tabular}

$*=$ one level Lowered by the methodology limitation by the methodology limitation

6. Lee, 2014

\begin{tabular}{|l|l|l|}
\hline Part/studies & Interpretation & Evid. Qual.
\end{tabular}

\begin{tabular}{|l|l|l}
\hline $15 / 1$ & Pain threshold increased after exercise & Very low*
\end{tabular}

* = one level Lowered by the methodology limitation by the methodology limitation

7. Hoffman study, 2004.

\begin{tabular}{|l|l|l|}
\hline Part/studies & Interpretation & Evid. Qual.
\end{tabular}

\begin{tabular}{|l|l|l}
\hline $12 / 0$ & Pain tolerance increased after exercise & Very low*
\end{tabular}

* = one level Lowered by the methodology limitation by the methodology limitation

bicycle show increasing the pain threshold/tolerance in healthy individuals. Possible explanations for this effect include increased heart rate analgesia, as there is evidence that there are common pathways between cardiovascular modulation and pain in the central nervous system $[33,40]$.

One factor that modulate the pain threshold/tolerance in the studies was the exercise intensity. The studies provided the intensity of exercise, demonstrating improvement in pain threshold at $75 \% \mathrm{HR}$ $\max , 75 \% \mathrm{VO}^{2} \max$ and other kind of intensity measurements (watts, $\mathrm{km} / \mathrm{h}$ and treadmill inclination), exposing that moderate/high intensity aerobic exercise improves pain threshold in healthy people. 
Table 3. Characteristic of each study

\begin{tabular}{|c|c|c|c|c|c|c|c|c|}
\hline $\mathbf{N}^{0}$ study & Modality & Intensity & Volume & Characterization & $\begin{array}{l}\text { Threshold } \\
\text { method }\end{array}$ & Gauging local & $\begin{array}{l}\text { Gauging } \\
\text { moment }\end{array}$ & Results \\
\hline 1 & $\begin{array}{l}\text { Ergometric } \\
\text { bicycle }\end{array}$ & 75\%Vo2máx & $\begin{array}{l}30 ', 3 x \text { Week for } 6 \\
\text { weeks }\end{array}$ & Vo2, HR, pain threshold & $\begin{array}{l}1 \mathrm{Kg} / \mathrm{cm} 2 / \mathrm{s} .3 \mathrm{x} \\
\text { and then mean }\end{array}$ & $\begin{array}{l}\text { Trapezius, } \\
\text { Biceps, Rectus } \\
\text { femoris, } \\
\text { Anterior tibial }\end{array}$ & $\begin{array}{l}\text { Before and after } \\
\text { exercise }\end{array}$ & $\begin{array}{l}\text { Increase of } \\
\text { pain threshold } \\
\text { after the } \\
\text { exercise }\end{array}$ \\
\hline 2 & $\begin{array}{l}\text { Ergometric } \\
\text { bicycle }\end{array}$ & $\begin{array}{l}\text { Increasing heart rate until } 75 \% \max \\
\text { HR frequency }\end{array}$ & $\begin{array}{l}15^{\prime} \text { at submaximal } \\
\text { test. } 2 \text { sets }\end{array}$ & $\begin{array}{l}\text { Age, Height and BMI. } \\
\text { Lactate, pain threshold }\end{array}$ & $\begin{array}{l}\text { Increasing } 1 \mathrm{~kg} / \\
\mathrm{cm} 2 / \mathrm{s} \text { until the } \\
\text { stimuli become } \\
\text { painful }\end{array}$ & $\begin{array}{l}\text { Hand, Back, } \\
\text { Calf }\end{array}$ & $\begin{array}{l}\text { Before and after } \\
\text { exercise }\end{array}$ & $\begin{array}{l}\text { Increase of } \\
\text { pain threshold } \\
\text { after the } \\
\text { exercise }\end{array}$ \\
\hline 3 & $\begin{array}{l}\text { Ergometric } \\
\text { bicycle }\end{array}$ & $\begin{array}{l}\text { Increasing } 10 \text { watts for minute, starting } \\
\text { at } 20 \text { watts, for } 6 \text { '. } 6 \text { sets until fatigue }\end{array}$ & $\begin{array}{l}2 \text { bouts } 6 \text { sets, } 90 " \text { rest } \\
\text { between sets }\end{array}$ & $\begin{array}{l}\text { Age, height, BMI, } \\
\text { densimetry, ODQ, SF36, } \\
\text { VAS }\end{array}$ & $\begin{array}{l}\text { Increase } 1 \mathrm{~kg} / \\
\mathrm{cm} 2 / \mathrm{s} \text { until the } \\
\text { stimuli become } \\
\text { painful }\end{array}$ & $\begin{array}{l}\text { Finger, Back, } \\
\text { Calf, Deltoid }\end{array}$ & $\begin{array}{l}\text { Before and after } \\
\text { exercise }\end{array}$ & $\begin{array}{l}\text { Increase of } \\
\text { pain threshold } \\
\text { after the } \\
\text { exercise }\end{array}$ \\
\hline 4 & $\begin{array}{l}\text { Ergometric } \\
\text { bicycle }\end{array}$ & $75 \%$ Vo2 max & 1 set, 30 & $\begin{array}{l}\text { PRS, HR, BP, SBP, } \\
\text { DBP, anxiety state }\end{array}$ & $\begin{array}{l}3 \mathrm{~kg} \text { pressure for } \\
2 \text { ' classifying } \\
\text { pain every } 15 \text { "' }\end{array}$ & palm & $\begin{array}{l}\text { Before, after } \\
5 \text { ' and after } 15\end{array}$ & $\begin{array}{l}\text { Increase of } \\
\text { pain threshold } \\
\text { after the } \\
\text { exercise }\end{array}$ \\
\hline 5 & Treadmill & $\begin{array}{l}5 \mathrm{~km} / \mathrm{h} \text { increasing inclination } \\
5^{\prime}-5^{\circ} \text { inclination, } 5^{\prime}-10^{\circ} \text { inclination } \\
5^{\prime}-15^{\circ} \text { inclination }\end{array}$ & 1 set: 15 & ND & $\begin{array}{l}16 \mathrm{~mm} 2 \text { contact } \\
\text { area. strength } \\
\text { gradually } \\
\text { increased, } \\
\text { increasing rate } \\
\text { of } 3 \mathrm{~N} / \mathrm{s} \text { until the } \\
\text { pain be reached }\end{array}$ & Thumb skin & $\begin{array}{l}\text { Before and after } \\
\text { exercise }\end{array}$ & $\begin{array}{l}\text { Increase of } \\
\text { pain threshold } \\
\text { after the } \\
\text { exercise }\end{array}$ \\
\hline 6 & Treadmill & $10^{\prime}-40^{\prime}$ to $6,5 \mathrm{~km} / \mathrm{h}$ & $1 \mathrm{set}$ & Age, Height, Weight & $\begin{array}{l}\text { Pressure } \\
\text { increase in ratio } \\
\text { of } 1 \mathrm{~kg} / \mathrm{s} \text { until } \\
\text { the subjects } \\
\text { experience the } \\
\text { pain }\end{array}$ & $\begin{array}{l}\text { Trigger points } \\
\text { (doesn't specify } \\
\text { the area) }\end{array}$ & $\begin{array}{l}\text { Before, } 10 \\
\text { during exercise } \\
\text { and immediately } \\
\text { after }\end{array}$ & $\begin{array}{l}\text { Increase of } \\
\text { pain threshold } \\
\text { after the } \\
\text { exercise }\end{array}$ \\
\hline 7 & Treadmill & $\begin{array}{l}10^{\prime}-75 \% \mathrm{HR} ; 30^{\prime}-50 \% \mathrm{HR} ; 30^{\prime}-75 \% \\
\text { HR }\end{array}$ & $\begin{array}{l}4 \text { bouts } \\
3 \text { sets: } 1^{\circ} \text { set, } 10^{\prime} 75 \% \\
\text { HR; } \\
2^{\circ} \text { set, } 30,50 \% \text { HR; } 3^{\circ} \\
\text { set, } 30^{\prime} 75 \% \text { HR }\end{array}$ & $\begin{array}{l}\text { VAS, height, Weight, } \\
\text { Vo2máx }\end{array}$ & $\begin{array}{l}\text { painful stimuli } \\
\text { applied for } 2 \\
\text { with } 9.8 \mathrm{~N} \text { and } \\
6.25 \mathrm{~mm} \text { contact } \\
\text { surface }\end{array}$ & Indicator finger & $\begin{array}{l}\text { Before, 10' } \\
\text { during exercise, } \\
30 \text { ' during } \\
\text { exercise, 5' after } \\
\text { and 30' after the } \\
\text { exercise }\end{array}$ & $\begin{array}{l}\text { Increased } \\
\text { pain threshold } \\
30 \text { ' group at } \\
75 \% \text { HR }\end{array}$ \\
\hline
\end{tabular}

Note: HR, heart rate. BMI, body mass index. ODQ, disability questionnaire. SF36, health questionnaire. VAS, visual analogic scale. PRS, pain scale. BP, blood pressure. SBP, systolic blood pressure. DBP, diastolic blood pressure

Some studies demonstrate moderate and high intensity training to increase also, pain threshold/tolerance and pain perception [41-43].

With respect to frequency of training (volume), only one study did training more than one week (Jones, 2014), training 3 times a week for 6 weeks. The other studies did not specify the weeks. Hoffman, 2004 did 4 bouts of training but no specify the days and weeks. Meeus, 2010 did 2 bouts of specific aerobic exercise. Koltyn, 1996, Whiteside, 2004 and Lee, 2014 did not specify the bouts, supposing that this study was acute exercise effect. However, participants performing acute, two or three or bouts per week on nonconsecutive days, demonstrating statistically significant improvement in pain threshold, in isometric exercise $(\mathrm{p}<0.05)$, strength and coordination exercise $(\mathrm{p}<0.05)$, aerobic exercise $(\mathrm{p}<0.05)$ and resistance training $(\mathrm{p}<0.05)[40,44-46]$.

Another spot in this study is that studies used only ergometric bicycle and treadmill exercises, not any other forms of aerobic exercise, such as swimming, rowing, skiing, etc. Swimming training demonstrated in the past to increases pain threshold in chronic pain subjects [47].

Advances have been made regarding the understanding of pain threshold/tolerance and exercise, there are several changes in pain threshold/tolerance between healthy subjects and pathologic. First, there is several differences between the pain modulatory through baroreceptor (pain modulation through cardiac impulse). Second, there is difference in the Central Pain Modulation (CPM) in the old days known as diffuse noxious inhibitory control (DNIC) in chronic condition. Finally, the nociceptive fibers regarding pain stimulus are different in healthy and pathological subjects. C fiber is attenuate in chronic conditions, intensifying the pain and elevating the stage to neuronal pain as well.

The present study demonstrated with low evidence quality that aerobic exercise increases pain threshold and tolerance in healthy subjects. Whetever, to understand how the pain threshold/tolerance can be effective in healthy subjects, studies must explain detailed method, such as, how many days of training per week, for how long, what intensity and the complementary information about the subjects.

The present review is not without limitations. First, the search was made only in English and Portuguese. Second, only one reviewer that performed the analysis of included studies, given higher risk of bias.

There is lack of information in the selected studies, it's became poor of information with respect of knowledge analysis. In the present study mostly of the found data are inconclusive. For this reason, caution must be used to interpreting the present results.

\section{Practical applications}

Analyzing the present review, some recommendations can be made regarding pain threshold in aerobic exercise in healthy human:

i) Initiate aerobic exercise with a sport science professional;

ii) Beginner should start the aerobic exercise in low intensity, increasing the volume through the weeks, and then the intensity; 
iii) One day a week of aerobic exercise is enough to elicit lower pain perception, but more days seems to better pain threshold.

iv) Start aerobic activity in ergometric bicycle if you have any knee injury and strengthen the muscles including at least one strength training per week.

Researchers and practitioners must be aware that some of the recommendations above are still limited in scientific publication. Further research is necessary to evaluate pain threshold in aerobic exercise modalities.

\section{Funding disclosure}

None of the authors have any funding disclosure to claim.

\section{References}

1. Bogduk HM (1994) Classification of chronic pain [Internet]. [cited 2018 Jul 10]. Available from: http://iasp-pain.org/Taxonomy?navItemNumber=576\#Pain

2. Pertovaara A, Huopaniemi T, Virtanen A, Johansson G (1984) The influence of exercise on dental pain thresholds and the release of stress hormones. Physiol Behav 33: 923-926. [Crossref]

3. Whiteside A, Hansen S, Chaudhuri A (2004) Exercise lowers pain threshold in chronic fatigue syndrome. Pain 109: 497-499. [Crossref]

4. Kruisdijk FR, Hendriksen IJ, Tak EC, Beekman AT, Hopman-Rock M (2012) Effect of running therapy on depression (EFFORT-D). Design of a randomized controlled trial in adult patients [ISRCTN 1894]. BMC Public Health 12: 50. [Crossref]

5. Weineck J (2003) Atividade física e esporte: para quê? 246 p.

6. Silva JA, Matsushima EH (2010) Mensurando o quinto sinal vital: a dor. Funpec (Ed.) $350 \mathrm{p}$.

7. Silva JA, Filho NPR (2006) Avaliação e mensuração de dor: pesquisa, teoria e prática. Funpec (ed.) $450 \mathrm{p}$.

8. Marchand S (2008) The physiology of pain mechanisms: from the periphery to the brain. Rheum Dis Clin North Am. 34: 285-309. [Crossref]

9. Melia M, Schmidt M, Geissler B, Konig J, Krahn U, et al. (2015) Measuring mechanical pain: the refinement and standardization of pressure pain threshold measurements. Behav Res Methods 47: 216-227. [Crossref]

10. Sands WA, McNeal JR, Murray SR, Stone MH (2015) Dynamic Compression Enhances Pressure-to-Pain Threshold in Elite Athlete Recovery: Exploratory Study. $J$ strength Cond Res 29: 1263-1272. [Crossref]

11. Torres-Chica B, Nunez-Samper-Pizarroso C, Ortega-Santiago R, Cleland JA, SalomMoreno J, et al. (2015) Trigger points and pressure pain hypersensitivity in people with postmeniscectomy pain. Clin J Pain 31: 265-272. [Crossref]

12. Kemppainen P, Pertovaara A, Huopaniemi T, Johansson G, Karonen SL (1985) Modification of Dental Pain and Cutaneous Thermal Sensitivity by Physical Exercise in Man. Brain Res 360 33-40. [Crossref]

13. Kemppainen P, Hamalainen O, Kononen M (1998) Different effects of physica exercise on cold pain sensitivity in fighter pilots with and without the history of acute in-flight neck pain attacks. Med Sci Sports Exerc 30: 577-88. [Crossref]

14. Ruble SB, Hoffman MD, Shepanski MA, Valic Z, Buckwalter JB, et al. (2005) Thermal pain perception after aerobic exercise. Arch Phys Med Rehabil 86:1019-1023. [Crossref]

15. Pertovaara A, Kemppainen P, Leppanen H (1992) Lowered cutaneous sensitivity to nonpainful electrical stimulation during isometric exercise in humans. Exp brain Res 89: 447-452. [Crossref]

16. Alstergren P, Forstrom J (2003) Acute oral pain intensity and pain threshold assessed by intensity matching to pain induced by electrical stimuli. J Orofac Pain 17: 151-159. [Crossref]

17. Drury DG, Greenwood K, Stuempfle KJ, Koltyn KF (2005) Changes in pain perception in women during and following an exhaustive incremental cycling exercise. $J$ Sport Sci Med 4: 215-222. [Crossref]

18. IASP. IASP Taxonomy. 2012
19. Larson AA, Brown DR, el-Atrash S, Walser MM (1986) Pain threshold changes in adjuvant-induced inflammation: a possible model of chronic pain in the mouse. Pharmacol Biochem Behav 24: 49-53. [Crossref]

20. Imamura M, Chen J, Matsubayashi SR, Targino RA, Alfieri FM, et al. (2013) Changes in pressure pain threshold in patients with chronic nonspecific low back pain. Spine 38 2098-2107. [Crossref]

21. Foo H, Westbrook RF (1991) Naloxone-induced hypoalgesia: effects of heat, cold and novelty. The Quarterly journal of experimental psychology B, Comparative and physiological psychology. Psychology 43: 137-156.

22. Olsen RB, Bruehl S, Nielsen CS, Rosseland LA, Eggen AE, et al. (2013) Hypertension prevalence and diminished blood pressure-related hypoalgesia in individuals reporting chronic pain in a general population: the Tromso study. Pain 154: 257-262. [Crossref]

23. Vance CG, Dailey DL, Rakel BA, Sluka KA (2014) Using TENS for pain control: the state of the evidence. Pain Manag 4: 197-209. [Crossref]

24. Koltyn KF (2002) Exercise-induced hypoalgesia and intensity of exercise. Sport Med 32: 477-87. [Crossref]

25. Koltyn KF, Brellenthin AG, Cook DB, Sehgal N, Hillard C (2014) Mechanisms of exercise-induced hypoalgesia. J pain 15: 1294-1304. [Crossref]

26. Henriksen M, Klokker L, Graven-Nielsen T, Bartholdy C, Joergensen TS, et al. (2013) Exercise Therapy Reduces Pain Sensitivity In Patients With Knee Osteoarthritis: A Randomized Controlled Trial. Arthritis Rheum 65: 775-781. [Crossref]

27. Madsen SM, Thorup AC, Overgaard K, Jeppesen PB (2015) High Intensity Interval Training Improves Glycaemic Control and Pancreatic beta Cell Function of Type 2 Diabetes Patients. PLoS One 10: 133-145. [Crossref]

28. Searle A, Spink M, Ho A, Chuter V (2015) Exercise interventions for the treatmen of chronic low back pain: A systematic review and meta-analysis of randomised controlled trials. Clin Rehabil 5: 104-115. [Crossref]

29. Hojman P, Gehl J, Christensen JF, Pedersen BK, et al. (2017) Molecular Mechanisms Linking Exercise to Cancer Prevention and Treatment. Cell Metab13: 243-251. [Crossref]

30. Turk Y, Theel W, Kasteleyn MJ, Franssen FME, Hiemstra PS, et al. (2017) High intensity training in obesity: a Meta-analysis. Obes Sci Pr 3: 258-271. [Crossref]

31. Leung A, Gregory NS, Allen LA, Sluka KA (2016) Regular physical activity prevent chronic pain by altering resident muscle macrophage phenotype and increasing interleukin-10 in mice. Pain 157: 70-79. [Crossref]

32. Landmark T, Romundstad PR, Borchgrevink PC, Dale O (2013) Longitudinal associations between exercise and pain in the general population-the HUNT pain study. PloS One 8: 65-79.

33. Bruehl SCOY, Ward P, Johnson B, McCubbin, JA (2002) The relationship between resting blood pressure and acute pain sensitivity in healthy normotensives and chronic back pain sufferers: the effects of opioid blockade. Pain 1: 191-201. [Crossref]

34. Stagg NJ, Mata HP, Ibrahim MM, Henriksen EJ, Porreca F, et al. (2011) Regular exercise reverses sensory hypersensitivity in a rat neuropathic pain model: role of endogenous opioids. Anesthesiology 114: 940-948. [Crossref]

35. Randich A, Maixner W (1984) Interactions between cardiovascular and pain regulatory systems. Neurosci Biobehav Rev 8: 343-367.

36. Whiteside AHS, Chaudhuri A (2004) Exercise lowers pain threshold in chronic fatigue syndrome. Pain 109: 497-499. [Crossref]

37. Pratley RE, Hagberg JM, Dengel DR, Rogus EM, Muller DC, et al. (2000) Aerobic exercise training-induced reductions in abdominal fat and glucose-stimulated insulin responses in middle-aged and older men. J Am Geriatr Soc 48: 1055-1061. [Crossref]

38. Gosselin LE, Kozlowski KF, DeVinney-Boymel L, Hambridge C (2012) Metabolic response of different high-intensity aerobic interval exercise protocols. $J$ strength Cond Res 26: 2866-2871. [Crossref]

39. Swartz MK (2011) The PRISMA statement: A guideline for systematic reviews and meta-analyses. J Pediatr Heal Care. 25: 1-2.

40. Koltyn K, Trine M, Stegner A, Tobar D (200) Effect of Isometric Exercise on Pain Perception in Rotator Cuff Related Shoulder Pain. Med Sci Sport Exerc 33: 282-90. [Crossref]

41. Sanz DR, Lopez-Lopez D, Garcia DM, Medrano AS, Ponce AM, et al. (2019) Effects of eccentric exercise in pressure pain threshold in subjects with functional ankle equinus condition. Rev Assoc Med Bras 65: 384-387. [Crossref] 
42. Ylinen J, Häkkinen A, Nykänen M, Kautiainen H, Takala EP (2007) Neck muscle training in the treatment of chronic neck pain: a three-year follow-up study. Eura Medicophys 43: 161-169. [Crossref]

43. Koltyn KF, Arbogast RW (1998) Perception of pain after resistance exercise. Br J Sport Med 32: 20-24. [Crossref]

44. Cook DB, Stegner AJ, Ellingson LD (2010) Exercise alters pain sensitivity in gulf war veterans with chronic musculoskeletal pain. J Pain 11: 764-772. [Crossref]
45. Henriksen M, Klokker L, Graven-Nielsen T, Bartholdy C, JØrgensen TS, et al. (2014) Association of exercise therapy and reduction of pain sensitivity in patients with knee osteoarthritis: A randomized controlled trial. Arthritis Care Res 66: 1836-1843. [Crossref]

46. Shi Z, Zhou H, Lu L, Pan B, Wei Z, Yao X, et al. (2017) Aquatic Exercises in the Treatment of Low Back Pain. Am J Phys Med Rehabil 97: 116-122. [Crossref]

Copyright: (C2020 Zecchin-Oliveira AM. This is an open-access article distributed under the terms of the Creative Commons Attribution License, which permits unrestricted use, distribution, and reproduction in any medium, provided the original author and source are credited. 